\title{
SCIENCE AND TECHNOLOGY OPPORTUNITIES IN HADITH RESEARCH
}

\section{Wahyudin Darmalaksana}

Faculty of Ushuluddin, UIN Sunan Gunung Djati Bandung

Corresponding Author Email: yudi_darma@uinsgd.ac.id

\begin{abstract}
The purpose of this research is to discuss the opportunities of science and technology in hadith research. This research method uses qualitative research through literature study with a content analysis approach. The results and discussion of this research include the hadith science methodology, the development of the hadith validity method and the hadith text criticism method with a multidisciplinary and transdisciplinary approach, and scientific and technological opportunities in hadith research for the need for integration of science. The conclusion of this study is that research on hadith with a transdisciplinary approach opens wide opportunities for science and technology that are currently developing for the realization of the integration of science. This study recommends the importance of applying a transdisciplinary approach to science and technology opportunities in the development of hadith research in Islamic higher education.
\end{abstract}

Keywords: science integration, research collaboration, hadith research, science and technology

\section{INTRODUCTION}

There are scientific and technological opportunities in hadith research. Since the modern Western century (Hardiyati, 2020), science and technology have progressed in human civilization (Ariyanto, 2018). In line with the advancement of Western science (Brown, 2020), hadith is studied from a modernist perspective (Idris, 2018). The motivation for the development of science from the hadith perspective is also examined (Darlis, 2017). Hadith research with modern science has become a new discourse (Akmaluddin, 2020). This hadith research discourse includes directions for the integration of science with social and natural sciences (Afwadzi, 2017). The opportunity for science and technology in hadith research has begun with the design of various applications of the validity of hadith (Darmalaksana et al., 2020) and also began research on the relation of hadith and science (Fudhail, 2020). This study highlights the opportunities of science and technology in hadith research in order to erode the dichotomy of science (Istikomah, 2019).

A number of previous studies have become a literature review of this research. Researchers have discussed the relationship between science and religion (Yahya et al., 2018), the relation between science and Islam (Dahlan, 2011). In the 1990s, there was a growing issue (Sookhdeo, 2006) of the Islamization of knowledge based on the Qur'an and hadith (Majid, 2018). Ontologically (Junaidi et al., 2017), the truth of the contents of the al-Qur'an and hadith is seen as a miracle of Islamic science (L. Ibrahim, 2010), until the science-technology dialectic took place with the Qur'an and hadith (Anam, 2012). Scholars try to dig up science and technology from the Qur'an and hadith (Nairozle et al., 2018). Specifically, scientific studies and hadith emerged (Z. al-Najjar, 2011), published scientific hadith master book (Z. R. M. al-Najjar \& Indrayadi, 2010), and research on the appropriateness of hadith and science (Fudhail, 2020). In the 2000s, research on hadith versus science (N. Ali, 2008) led to the convergence of science and Islam (Umar, 2016).

* Copyright (c) 2021 Wahyudin Darmalaksana

This work is licensed under a Creative Commons Attribution-ShareAlike 4.0 International License.

Received: September 26, 2020; In Revised: January 18, 2021; Accepted: January 27, 2021 
IJIK, Vol.11 No. 1: 41-51

Science and Technology Opportunities in Hadith Research

Wahyudin Darmalaksana

Researchers acknowledge the role of modern science in the interaction of hadith texts (M. Y. Ismail, 2016), particularly the contribution of science in determining the validity of the hadith (Hasibuan, 2017). In 2015, a number of researches on the integration of science-technology and hadith took place (Mahmud \& Arafah, 2020). Research around this includes the integration of knowledge in hadith (Wahid, 2017), integration of social science and hadith (Afwadzi, 2016b), hadith research with a mulidisciplinary approach from the natural sciences (Afwadzi, 2016a), and application of integration of natural sciences with the understanding of hadith (Afwadzi, 2017). There is also research on the integration of science in the hadith text criticism (Firdaus \& Suryadilaga, 2019). The integration of knowledge in the study of hadith is found in a number of dissertation studies (Lukman, 2017).

Literature review of the hadith with respect to science and technology is useful for constructing a frame of mind. Hadith is understood as a paradigm (Wendry et al., 2018). From a review of the philosophy of science (Adib, 2011), hadith paradigm (Darmalaksana, 2018) includes ontology (Junaidi et al., 2017), epistemology (Atabik, 2017), and axiology (Solihin, 2016). Ontologically, the hadith is the source of Islam (Fageh, 2019). Epistemologically (Amaliya, 2015), hadith is a collection of hadith science methodology (Nadhiran, 2017). Axiologically (Basid, 2016), hadith is the main value of the application of Islam (Hasbillah, 2019). It is known that the science of hadith has developed in history (Zuhri, 2015), along with the advancement of science in the Western world (Hardiyati, 2020). In classical times (I. Fauzi, 2020), hadith research applies the approach of Islamic sciences (Kurniati, 2020). In modern times (Saifullah, 2014), hadith research has begun to apply a multidisciplinary approach (Rohmatika, 2019). This is an opportunity for science and technology in hadith research (Aditoni, 2019). Advances in information technology can be used for validity testing (Baraka \& Dalloul, 2014). Hadith can be an inspiration for the development of science and technology (Mustami \& Masri, 2017). Hadith research through a science and technology approach is needed to realize the integration of science (Wahid, 2017).

Based on the explanation above, a research formula is prepared, namely the formulation of the problem, research questions, and research objectives (Darmalaksana, 2020b). The formulation of the research problem is that there are opportunities for science and technology in hadith research. This research question is how the opportunities of science and technology in hadith research. The purpose of this research is to discuss the opportunities of science and technology in hadith research. This research is expected to be useful for the development of hadith research in the era of globalization of information (Suryadilaga, 2014).

\section{METHODOLOGY}

This research method uses qualitative research through literature study (Darmalaksana, 2020c, 2020f). The data interpretation in this study used a content analysis approach (Hsieh \& Shannon, 2005; Williamson et al., 2018). Literature study is carried out by collecting various sources of hadith research related to science and technology. Furthermore, a content analysis approach was carried out for all sources. This content analysis approach aims to reveal the development of hadith research in the modern era that cannot be separated from science and technology.

\section{RESULT AND DISCUSSION}

Hadith and the science of hadith have developed in history (Wahid \& Masri, 2018), from oral to digital traditions (Maulana, 2016). Hadith is something that comes from the Prophet which includes words, deeds, statements and others (Soetari, 1994). Hadith is also called sunnah, Hadith is a collection of 
IJIK, Vol.11 No. 1: 41-51

Science and Technology Opportunities in Hadith Research

Wahyudin Darmalaksana

hadith found in hadith books, and sunnah are Muslim practices in tradition and culture (Soetari, 1994). In the Islamic world, the hadith is agreed as the second source of Islam after the al-Qur'an (Darmalaksana et al., 2017).

In general, the science of hadith is divided into two, namely the history of hadith transmission and the methodology of hadith science (Soetari, 2005). The history of hadith narration discusses the origin of the hadith since its transmission from the Prophet, passed on to people from generation to generation, and recorded in the hadith book (Soetari, 2005). The methodology of hadith science serves to test the authenticity of the hadith whether it is true from the Prophet or false traditions (Masrur, 2012).

Hadith knowledge has developed (Andariati, 2020), from the classical period to the contemporary era (Anggoro, 2019). First, developed the method of hadith takhrij (Qomarullah, 2016) to test the authenticity and validity of the hadiths by extracting the hadiths from the hadith book (Soetari, 2015). Second, developed the method of sharah hadith (Muhtador, 2016) to explain the meaning of the hadith text (Sagir, 2017). In the sharah hadith method, a textual approach develops through linguistic analysis and a contextual approach (Alamsyah et al., 2020) through analysis of the causes of the emergence of the hadith (Lestari, 2015) and social sciences (Suryadilaga, 2017), such as anthropology (Rohmana, 2015), sociology (Assagaf, 2015), genealogy (Taufik, 2020a), and others.

The government in Indonesia has established policies regarding the development of hadith research (Tim Penyusun, 2018b). The policy stipulates that hadiths should be researched using an interdisciplinary, multidisciplinary and transdisciplinary approach (Tim Penyusun, 2018a). Interdisciplinarity is research with an allied scientific approach (Rohmatika, 2019). Multidisciplinary is research with a science approach that is not related (Rohmatika, 2019). Transdisciplinarity is research with an integrated science approach (Sudikan, 2015). This policy is in line with regulations regarding the implementation of integrated science between Islamic and general sciences in Islamic higher education in Indonesia (Indonesia, 2019).

Today there are opportunities for science and technology in hadith research. First, the use of advances in information technology in hadith research. The use of information technology plays a role in the development of the hadith takhrij method (Darmalaksana, 2020d). Second, the use of hadith as inspiration for the development of science and technology. This is an opportunity for the development of the sharah hadith method through a multidisciplinary and transdisciplinary approach from advances in science and technology (Taufik, 2020b).

Information technology plays a role in the development of the hadith takhrij method, both hadith narrative research and hadith text research (T. M. S. T. Ismail et al., 2014). Hadith science establishes five indicators of the validity of hadith, namely: 1) continuity of hadith narration; 2) the quality of the hadith narrators; 3) capacity of hadith narrators; 4) the validity of the hadith text; dan 5) the purity of the hadith text. In classical times, hadith scholars validated hadith using conventional methods (M. A. M. Ali et al., 2015). In the modern era, hadith scholars have made innovative use of advances in information technology (Najeeb, 2014) in testing the validity of the hadith (Baraka \& Dalloul, 2014).

The digital information about the hadiths has prepared a rich resource (Alkhatib et al., 2017). This condition is an opportunity for researchers to design a hadith search engine (Darmalaksana et al., 2020) with a multi-language system (Hassan \& Atwell, 2016), so that hadith researchers can assess the quality of hadith information (Karim \& Hazmi, 2005). Retrieval of hadith information from digital data sets (Mahmood et al., 2017) is beneficial for the discovery of hadith knowledge (Jbara, 2010). Hadith researchers play a role in determining the validity of the hadith (Ghazizadeh et al., 2008) and the 
authenticity of the hadith (Hakak et al., n.d.) by displaying the visualization of the chain of hadith narrators (Shukur et al., 2011).

Operationally, hadith research includes mining hadith data (Saloot et al., 2016) and processing of hadith literature (A. M. Azmi et al., 2019) by using a multi-agent system (Najeeb, 2015), resulting in the classification of hadith (Alkhatib, 2010). Based on this information technology, various classifications of hadith can be obtained, such as positive and negative hadith classifications (Al Faraby et al., 2018), hadith degree classification (Najiyah et al., 2017), hadith classification matching (Hasan et al., 2018), and topical classification of hadith texts (Al-Kabi et al., 2015). Information technology experts are able to design machines to improve the extraction of hadith classifier knowledge (Aldhaln et al., 2012) and they are able to improve the performance of the hadith classification (Aldhlan et al., 2012). This is the development of information technology on hadith verification techniques (Yusoff et al., 2010) with regard to hadith indexing (Harrag et al., 2008).

In addition, the hadith can be understood with a modern scientific approach (Abd Razzak, 2011). Among them is the hadith perspective on management (Hamid \& Sa'ari, 2011), economic system (Usman et al., 2015)' and a collection of hadith about economics (Idri, 2010). Hadith also discusses medicine (Deuraseh, 2006), health (Akbar \& Budiyanto, 2020), epidemic of a disease (A. S. Azmi, 2020), treatment (Safarsyah, 2018), healing with honey (Taghavizad, 2011), and traditions about pharmacy (Dalil, 2017). Specifically, the hadith deals with dental health (A. Fauzi, 2018), natural toothbrush (Niazi et al., 2016), and the Prophet's teachings on oral health (Aumeeruddy et al., 2018). This has become an inspiration for dentistry in modern times (Marzband \& Karnami, 2016).

It was found that there was inspiration in health science from the experience of the Prophet (Awang \& Robbi, 2020). The Prophet taught health for life (Lazim, 2018), he teaches fasting for the immune system (Mostafazadeh \& Khorasani, 2014), and the Prophet taught a healthy lifestyle (Fadli et al., 2019). The hadith emphasizes cleanliness and environmental health (Rahmasari, 2017), including hadith discussing rain and floods (Zulhelmi \& Azman, 2016). There is also research which states that hadith is an object of physics (Mirza, 2016). Also explained about the truth of hadith from the perspective of physics science (Harahap, 2017).

Hadith also discusses biology issues, such as the hadith understanding of genes from a scientific perspective (Setyani, 2016), the reproductive process of women from the perspective of the hadith (Rofiq, 2015), and the interrelation of organs from the hadith perspective (Nashiruddin, 2017). There is also plant biology in the understanding of hadith (Baihaqi, 2018). Also animal biology according to the hadith with a scientific approach (Tsaqofi, 2018). The rest, the hadith discusses types of flies (Fikriyati, 2019). In fact, this hadith about flies has inspired research into the production of anti-bacteria from the wings of various types of flies (Mustami \& Masri, 2017). Matters regarding iron material are also discussed in the hadith (Salmah, 2017).

Hadith is not everything in the face of science and technology. In fact, science and technology are developing very fast (Hardiyati, 2020). While the science of hadith is still looking for a form of development (Darmalaksana, 2020e). However, the hadith can inspire the development of science and technology (Mustami \& Masri, 2017). It is undeniable that it turns out that there are many traditions related to science (Nairozle et al., 2018). Of course this can be an opportunity for science and technology to encourage the development of hadith research in the future (Abbas, 2019).

Especially with regard to advances in information technology, then the science of hadith can use it for applied methodology (Hasibuan, 2017). The method of hadith takhrij can be developed in the latest through advances in information technology (Darmalaksana, 2020d). So that information technology 
IJIK, Vol.11 No. 1: 41-51

Science and Technology Opportunities in Hadith Research

Wahyudin Darmalaksana

plays a role in facilitating the process of validating the hadiths from digital big data sets (Darmalaksana, 2020a). Hadith experts can conduct collaborative research with engineering circles to design applications of hadith authenticity. Hadith experts are tasked with compiling hadith validation business processes based on the theory of hadith science, and engineers are tasked with designing hadith applications with a cutting-edge approach. Collaboration is an important part of the development of science in this multidisciplinary era (Darmalaksana, 2020d).

Collaborative research on hadith and technology can take many forms, such as: 1) Data mining technology (Jiawei et al., 2012) and text mining (Zohar, 2002), who are able to seek insight knowledge from databases and hadith texts with classification, clustering, and association approaches that produce rules or semantics from hadith; 2) Natural language processing technology (Chowdhury, 2005; Nadkarni et al., 2011), like opinion mining (Jumadi et al., 2016) and sentiment analysis (Branz \& Brockmann, 2018) which can be used to find out a person's opinion and sentiment in evaluating a hadith, text summarization which can be used to summarize the journey of hadith (Adytoma, 2019), and translation machine (Zong \& Hong, 2018) which can be used to automatically translate the hadiths into various languages; 3) Information retrieval that can be used to create a hadith search engine (Darmalaksana et al., 2020); to 4) eLearning which can be used for learning and introduction to hadith in the world of education, where currently many e-learning are presented with augmented reality technology (Dunleavy \& Dede, 2014; Nincarean et al., 2013).

Only authenticity research (N. K. Ibrahim etal., 2016) is not sufficient in the study of hadith criticism (Yaqub, 2004). Furthermore, the study of hadith texts is needed (Pari, 2017). Usually a contextual approach is used in understanding the hadiths (Shah, 2011). Although the contextual approach is considered current in the study of hadith texts (Idris, 2018), but hadith research still requires a transdisciplinary approach (Hadorn etal., 2008). Based on a transdisciplinary approach to hadith research (Sudikan, 2015), it will result in an integration between hadith and science, so that there is no dichotomy between hadith and science (Istikomah, 2019).

\section{CONCLUSION}

Hadith research has opened up opportunities for the development of science and technology. Advances in information technology are useful for designing hadith validity applications. At the same time, the development of science is beneficial for the development of hadith research. Multidisciplinary and transdisciplinary approaches are needed in hadith research. The implication is that hadith research can produce valid, contextual, and transformative traditions in line with advances in science and technology. Another implication is that cross-disciplinary collaborative research is needed so that it results in an integration of knowledge between hadith and science-technology. This research is expected to be useful for Muslim scientists for integrated research between science-technology and hadith. This study has the limitation of only an initial study with a literature review, so that further research is needed in an integral, comprehensive, and in-depth manner. This study recommends the importance of applying a transdisciplinary approach to science and technology opportunities in the development of hadith research in Islamic higher education.

\section{REFERENCES}

Abbas, N. (2019). Masa Depan Hadis Dan 'Ulum Al-Hadis (Suatu Gagasan Ke Arah Pembaruan Pemikiran Hadis). Sulesana: Jurnal Wawasan Keislaman, 13(1), 41-63.

Abd Razzak, M. (2011). Punica Granatum Bicara Al-Quran, Al-Hadith Dan Sains Perubatan Moden. Al- 
Bayan: Journal of Qur'an and Hadith Studies, 9(1), 1-20.

Adib, H. M. (2011). Filsafat Ilmu: Ontologi, Epistemol ogi, Aksiologi, dan Logika Ilmu Pengetahuan. Pustaka Pelajar.

Aditoni, A. (2019). Studi Islam di Indonesia: Peluang dan Tantangan. PROCEEDING IAIN Batusangkar, $4(1), 5-16$.

Adytoma, W. W. (2019). Peringkasan teks otomatis Hadis Shalat menggunakan algoritma Bellman Ford. UIN Sunan Gunung Djati Bandung.

Afwadzi, B. (2016a). Memahami Eksistensi Pendekatan Ilmu-ilmu Alam dan Pemahaman Hadis Nabi.

Afwadzi, B. (2016b). Membangun Integrasi Ilmu-Ilmu Sosial dan Hadis Nabi. Jurnal Living Hadis, 1(1), 101-128.

Afwadzi, B. (2017). Integrasi ilmu-ilmu alam dan ilmu-ilmu sosial dengan pemahaman hadis Nabi: Telaah atas konsepsi, aplikasi, dan implikasi. Theologia, 28(2), 351-390.

Akbar, D. L., \& Budiyanto, B. (2020). Konsep Kesehatan Dalam Al-Qur'an Dan Hadis. Al-Bayan: Jurnal Ilmu Al-Qur'an Dan Hadist, 3(2), 157-173.

Akmaluddin, M. (2020). Diskursus Penelitian Al-quran dan Hadis dengan Ilmu Pengetahuan Modern. Seminar Nasional Hasil Penelitian Dan Pengabdian Masyarakat UNIMUS 2017.

Al-Kabi, M. N., Wahsheh, H. A., Alsmadi, I. M., \& Al-Akhras, A. M. A. (2015). Extended topical classification of hadith Arabic text. Int. J. Islam. Appl. Comput. Sci. Technol, 3(3), 13-23.

al-Najjar, Z. (2011). Sains Dalam Hadis. Mengungkap Fakta Ilmiah Dari Kemukjizatan Hadis Nabi, Jakarta: Amzah.

al-Najjar, Z. R. M., \& Indrayadi, Y. (2010). Buku induk mukjizat ilmiah hadis nabi: menyibak fakta-fakta ilmiah dalam sabda Rasulullah yang kebenarannya baru tersiangkapkan di era kemajuan sains dan teknologi. Penerbit Zaman.

Al Faraby, S., Jasin, E. R. R., \& Kusumaningrum, A. (2018). Classification of hadith into positive suggestion, negative suggestion, and information. Journal of Physics: Conference Series, 971(1), 12046.

Alamsyah, A., Siti, M., \& Syamsul, H. (2020). The Contextualization of Hadith in Indonesia: Nusantara Ulema's Response to Islamists. International Journal of Psychosocial Rehabilitation, 24(7), 15481558.

Aldhaln, K., Zeki, A., Zeki, A., \& Alreshidi, H. (2012). Improving knowledge extraction of Hadith classifier using decision tree algorithm. 2012 International Conference on Information Retrieval \& Knowledge Management, 148-152.

Aldhlan, K. A., Zeki, A. M., Zeki, A. M., \& Alreshidi, H. A. (2012). Novel mechanism to improve hadith classifier performance. 2012 International Conference on Advanced Computer Science Applications and Technologies (ACSAT), 512-517.

Ali, M. A. M., Ibrahim, M. N., Usman, A. H., Nazri, M. A., \& Kadir, M. N. A. (2015). Al-Jarh Wa Al-Ta'dil (Criticism and Praise): It's Significant in the Science of Hadith. Mediterranean Journal of Social Sciences, 6(2 S1), 284.

Ali, N. (2008). Hadis Versus Sains: Memahami Hadis-Hadis Musykil. In Yogyakarta: Teras.

Alkhatib, M. (2010). Classification of Al-Hadith Al-Shareef using data mining algorithm. European, Mediterranean and Middle Eastern Conference on Information Systems, EMCIS2010, Abu Dhabi, UAE, $1-23$.

Alkhatib, M., Monem, A. A., \& Shaalan, K. (2017). A Rich Arabic WordNet Resource for Al-Hadith AlShareef. Procedia Computer Science, 117, 101-110.

Amaliya, N. K. (2015). Epistemologi Hadis. QALAMUNA-Jurnal Pendidikan, Sosial, Dan Agama, 7(1), 107119.

Anam, N. (2012). Al-Qur'an dan Hadis: Dialektika Sains-Teknologi dan Ilmu Agama. Dalam Jurnal Al'Adalah, 16(2).

Andariati, L. (2020). Hadis dan Sejarah Perkembangannya. Diroyah: Jurnal Studi Ilmu Hadis, 4(2).

Anggoro, T. (2019). Perkembangan Pemahaman Hadis Di Indonesia: Analisis Pergeseran Dan Tawaran Di Masa Kini. Diya Al-Afkar: Jurnal Studi Al-Quran Dan Al-Hadis, 7(01), 147-166.

Ariyanto, D. A. S. (2018). Sains dan teknologi dalam perkembangan peradaban manusia. Seminar Nasional Pendidikan Teknik Otomotif.

Assagaf, J. (2015). Studi Hadis Dengan Pendekatan Sosiologis: Paradigma Living-Hadis. Holistic Al-Hadis, 
1(2), 289-316.

Atabik, A. (2017). Epistemologi Hadis: Melacak Sumber Otentitas Hadis. RELIGIA.

Aumeeruddy, M. Z., Zengin, G., \& Mahomoodally, M. F. (2018). A review of the traditional and modern uses of Salvadora persica L.(Miswak): Toothbrush tree of Prophet Muhammad. Journal of Ethnopharmacology, 213, 409-444.

Awang, A. B., \& Robbi, A. A. M. (2020). Health Science: Medical Treatment In Prophet's Behaviour Context/Sains Kesihatan: Perubatan Dalam Konteks Tasarrufat Nabawiyyah. Sains Humanika, $12(2)$.

Azmi, A. M., Al-Qabbany, A. O., \& Hussain, A. (2019). Computational and natural language processing based studies of hadith literature: a survey. Artificial Intelligence Review, 52(2), 1369-1414.

Azmi, A. S. (2020). 40 Hadis tentang wabak penyakit. Ulum Hadith Research Centre.

Baihaqi, A. (2018). Pemahaman Larangan Menebang Pohon Bidara (Studi Kajian Kualitas Sanad Hadis Dan Pemahaman Hadis). Jakarta: Fakultas Ushuluddin Dan Filsafat UIN Syarif Hidayatullah.

Baraka, R. S., \& Dalloul, Y. (2014). Building Hadith ontology to support the authenticity of Isnad. Building Hadith Ontology to Support the Authenticity of Isnad, 2(1).

Basid, A. (2016). Takhrîj al-Hadîth dalam Perspektif Kajian Ontologi dan Aksiologi Ilmu Hadis. Tafáqquh: Jurnal Penelitian Dan Kajian Keislaman, 4(1), 78-91.

Branz, L., \& Brockmann, P. (2018). Sentiment Analysis of Twitter Data. Proceedings of the 12th ACM International Conference on Distributed and Event-Based Systems - DEBS '18. https://doi.org/10.1145/3210284.3219769

Brown, D. W. (2020). Western Hadith Studies. The Wiley Blackwell Concise Companion to the Hadith, 3956.

Chowdhury, G. G. (2005). Natural language processing. Annual Review of Information Science and Technology. https://doi.org/10.1002/aris.1440370103

Dahlan, M. (2011). Relasi Sains Modern dan Sains Islam Suatu Upaya Pencarian Paradigma Baru. Jurnal Salam, 12(2).

Dalil, F. Y. M. (2017). Hadis-Hadis tentang Farmasi; Sebuah Kajian Integratif dalam Memahami Hadis Rasulullah. PROCEEDING IAIN Batusangkar, 1(1), 309-326.

Darlis, A. (2017). Motivasi Pengembangan Ilmu Pengetahuan Dalam Perspektif Hadis Nabi. POTENSIA: Jurnal Kependidikan Islam, 3(1), 1-28.

Darmalaksana, W. (2018). Paradigma Pemikiran Hadis. Jurnal Aqidah Dan Filsafat Islam, 2(1), 95-106.

Darmalaksana, W. (2020a). Big Data, Pengetahuan Sistematis, dan Kecerdasan Kolektif: Studi Kasus Pembelajaran Metode Penelitian Hadis. Pre-Print Digital Library UIN Sunan Gunung Djati Bandung, 1.

Darmalaksana, W. (2020b). Formula Penelitian Pengalaman Kelas Menulis. Jurnal Kelas Menulis UIN Sunan Gunung Djati Bandung.

Darmalaksana, W. (2020c). Metode Penelitian Kualitatif Studi Pustaka dan Studi Lapangan. Pre-Print Digital Library UIN Sunan Gunung Djati Bandung.

Darmalaksana, W. (2020d). Prosiding Proses Bisnis Validitas Hadis untuk Perancangan Aplikasi Metode Tahrij. Jurnal Ushuluddin UIN Sunan Gunung Djati Bandung, 1, 1-7.

Darmalaksana, W. (2020e). Rencana Implementasi Penelitian Hadis pada Pendidikan Tinggi Indonesia: Sebuah Analisis Kebijakan. Jurnal Hadis Fakultas Ushuluddin UIN Sunan Gunung Djati Bandung.

Darmalaksana, W. (2020f). Studi Penggunaan Analisis Pendekatan Ilmu-ilmu Sosial dalam Penelitian Hadis Metode Syarah. Khazanah Sosial, 2(3), 155-166.

Darmalaksana, W., Pahala, L., \& Soetari, E. (2017). Kontroversi Hadis sebagai Sumber Hukum Islam. Wawasan: Jurnal Ilmiah Agama Dan Sosial Budaya, 2(2), 245-258.

Darmalaksana, W., Slamet, C., Zulfikar, W. B., Fadillah, I. F., Maylawati, D. S., \& Ali, H. (2020). Latent semantic analysis and cosine similarity for hadith search engine. Telkomnika, 18(1).

Deuraseh, N. (2006). Health and medicine in the Islamic tradition based on the book of medicine (Kitab Al-Tibb) of Sahih Al-Bukhari. JISHIM, 5, 2-14.

Dunleavy, M., \& Dede, C. (2014). Augmented reality teaching and learning. In Handbook of Research on Educational Communications and Technology: Fourth Edition. https://doi.org/10.1007/978-14614-3185-5_59 
Fadli, S. N. I. A., Mokhtar, W. K. A. W., Amiruddin, E., Rashid, R. A., Idris, M. F. H. M., \& Salleh, A. Z. (2019). Healthy Lifestyle of Prophet Muhammad SAW. INTERNATIONAL JOURNAL OF ACADEMIC RESEARCH IN BUSINESS AND SOCIAL SCIENCES, 9(11).

Fageh, A. (2019). Analisa Ontologi dan Epistemologi Hadis Perspektif Ibn Taimiyah. TARBIYA ISLAMIA: Jurnal Pendidikan Dan Keislaman, 8(2), 134-148.

Fauzi, A. (2018). Kontekstualisasi Makna Hadis Siwak Melalui Pendekatan Hermeneutika Fazlur Rahman. Journal of Hadith Studies, 1(2).

Fauzi, I. (2020). Hadits dari Klasik Literal ke Portable Digital: Telaah Aplikas Smartphone Mausu'ah alHadits al-Syarif Islamweb. Riwayah: Jurnal Stud Hadits, 6(1).

Fikriyati, U. U. (2019). Hadis Dhubābah Perspektif Teori Parity danSymmetric Universe. Jurnal Living Hadis, 4(1), 27-44.

Firdaus, M. T., \& Suryadilaga, M. A. (2019). Integrasi Keilmuan Dalam Kritik Matan Hadis. TAJDID: Jurnal Ilmu Ushuluddin, 18(2), 153-176.

Fudhail, A. (2020). Menjawab Keraguan Maurice Bucaille tentang Kesesuaian Hadis dan Sains. Refleksi, 19(1).

Ghazizadeh, M., Zahedi, M. H., Kahani, M., \& Bidgoli, B. M. (2008). Fuzzy expert system in determining Hadith 1 validity. In advances in computer and information sciences and engineering (pp. 354-359). Springer.

Hadorn, G. H., Hoffmann-Riem, H., Biber-Klemm, S., Grossenbacher-Mansuy, W., Joye, D., Pohl, C., Wiesmann, U., \& Zemp, E. (2008). Handbook of transdisciplinary research (Vol. 10). Springer.

Hakak, S., Kamsin, A., Zada Khan, W., Zakari, A., Imran, M., bin Ahmad, K., \& Amin Gilkar, G. (n.d.). Digital Hadith authentication: Recent advances, open challenges, and future directions. Transactions on Emerging Telecommunications Technologies, e3977.

Hamid, S. A., \& Sa'ari, C. Z. (2011). Reconstructing entrepreneur's development based on al-Qur'an and al-Hadith. International Journal of Business and Social Science, 2(19).

Harahap, A. A. (2017). Kebenaran Al Qur'an dan Hadits Dari Sudut Pandang Fisika Sains. AXIOM: Jurnal Pendidikan Dan Matematika, 6(2).

Hardiyati, M. (2020). Sejarah Perkembangan Ilmu Dunia Barat. Prosiding Konferensi Integrasi Interkoneksi Islam Dan Sains, 2, 11-16.

Harrag, F., Hamdi-Cherif, A., \& El-Qawasmeh, E. (2008). Vector space model for Arabic information retrieval-application to "Hadith" indexing. 2008 First International Conference on the Applications of Digital Information and Web Technologies (ICADIWT), 107-112.

Hasan, A. M., Rassem, T. H., \& Noorhuzaimi, M. N. (2018). Combined support vector machine and pattern matching for arabic islamic hadith question classification system. International Conference of Reliable Information and Communication Technology, 278-290.

Hasbillah, A. (2019). Ilmu Living Qur'an-hadis: Ontologi, Epistemologi, dan Aksiologi. Tangerang: Maktabah Darus-Sunnah.

Hasibuan, M. I. A. (2017). Kontribusi Sains dalam Menentukan Kualitas Hadis. EDU-RILIGIA: Jurnal Ilmu Pendidikan Islam Dan Keagamaan, 1(3).

Hassan, S. M. O., \& Atwell, E. S. (2016). Concept search tool for multilingual hadith corpus. International Journal of Science and Research (IJSR), 5(4), 1326-1328.

Hsieh, H.-F., \& Shannon, S. E. (2005). Three approaches to qualitative content analysis. Qualitative Health Research, 15(9), 1277-1288.

Ibrahim, L. (2010). Keajaiban Sains Islam: Mengungkap Kebenaran Isi Alquran dan Hadis dengan Logika dan Ilmu Pengetahuan. In Yogyakarta: Pinus Book Publisher.

Ibrahim, N. K., Noordin, M. F., Samsuri, S., Seman, M. S. A., \& Ali, A. E. B. (2016). Isnad Al-Hadith Computational Authentication: An Analysis Hierarchically. 2016 6th International Conference on Information and Communication Technology for The Muslim World (ICT4M), 344-348.

Idri, H. (2010). Hadis Ekonomi: Ekonomi dalam Perspektif Hadis Nabi. Kencana.

Idris, M. (2018). Metode Pemahaman Hadis Modernis. Jurnal Ulunnuha, 7(1), 29-39.

Indonesia, K. A. R. (2019). Pedoman Implementasi Integrasi Ilmu di Perguruan Tinggi Keagamaan Islam. Direktorat Pendidikan Tinggi Keagamaan Islam Direktorat Jenderal Pendidikan.

Ismail, M. Y. (2016). Peranan Sains Moden dalam Interaksi teks Hadis: Penelitian Terhadap Hadis 
Berkaitan Penciptaan Janin Manusia.

Ismail, T. M. S. T., Baru, R., Hassan, A. F., Salleh, A. Z. Bin, \& Amin, M. F. M. (2014). The matan and sanad criticisms in evaluating the hadith. Asian Social Science.

Istikomah, I. (2019). Integrasi Sains dan Agama Di Perguruan Tinggi Sebagai Upaya Mengikis Dikotomi Ilmu. Tadrisuna: Jurnal Pendidikan Islam Dan Kajian Keislaman, 2(1), 66-78.

Jbara, K. (2010). Knowledge discovery in Al-Hadith using text classification algorithm. Journal of American Science, 6(11), 409-419.

Jiawei, H., Kamber, M., Han, J., Kamber, M., \& Pei, J. (2012). Data Mining: Concepts and Techniques. In San Francisco, CA, itd: Morgan Kaufmann. https://doi.org/10.1016/B978-0-12-381479-1.00001-0

Jumadi, Maylawati, D. S., Subaeki, B., \& Ridwan, T. (2016). Opinion mining on Twitter microblogging using Support Vector Machine: Public opinion about State Islamic University of Bandung. Proceedings of 2016 4th International Conference on Cyber and IT Service Management, CITSM 2016. https://doi.org/10.1109/CITSM.2016.7577569

Junaidi, J., Jamal, I. H., Ghazali, N. M., Ahmad, H., \& Salam, R. A. (2017). Expanding hadith understanding using ontology. Advanced Science Letters, 23(5), 4611-4614.

Karim, N. S. A., \& Hazmi, N. R. (2005). Assessing Islamic information quality on the Internet: A case of information about hadith. Malaysian Journal of Library \& Information Science, 10(2), 51-66.

Kurniati, Y. (2020). Rekonstruksi Metodologi Keilmuan Syarah Hadis Klasik. Islam Transformatif: Journal of Islamic Studies, 4(1), 46-56.

Lazim, M. N. (2018). Memahami hadis tentang menguap: studi kritis dengan tinjauan sains. UIN Walisongo Semarang.

Lestari, L. (2015). Epistemologi Ilmu Asbab al-Wurud Hadis. Jurnal Studi Ilmu-Ilmu Al-Qur'an Dan Hadis, 16(2), 265-285.

Lukman, F. (2017). Integrasi-Interkoneksi dalam Studi Hadis Disertasi Di Uin Sunan Kalijaga Yogyakarta. RELIGIA, 1-11.

Mahmood, A., Khan, H. U., \& Khan, W. (2017). Query based information retrieval and knowledge extraction using Hadith datasets. 2017 13th International Conference on Emerging Technologies (ICET), 1-6.

Mahmud, M., \& Arafah, R. N. (2020). Air Zam-zam dalam Perspektif Hadis dan Sains (Upaya Mendamaikan Agama dan Sains). Prosiding Konferensi Integrasi Interkoneksi Islam Dan Sains, 2, 219-223.

Majid, A. (2018). Islamisasi Ilmu Dan Relevansi Sains-Agama Dalam Al-Qur'an Dan Hadis. Jurnal Ilmiah Al-Mu'ashirah, 15(1), 28-39.

Marzband, R., \& Karnami, S. H. H. (2016). The orodental healthcare based on Islamic Traditions (Hadith). International Journal of Medical Research \& Health Sciences, 5(2), 36-41.

Masrur, A. (2012). Diskursus Metodologi Studi Hadis Kontemporer Analisa Komparatif antara Pendekatan Tradisional dan Pendekatan Revisionis. Journal of Qur'an and Hadith Studies, 1(2), 237-249.

Maulana, L. (2016). Periodesasi Perkembangan Studi Hadits (Dari Tradisi Lisan/Tulisan Hingga berbasis Digital). ESENSIA: Jurnal Ilmu-Ilmu Ushuluddin, 17(1), 111-123.

Mirza, S. Z. (2016). The Peoples' Hadith: Evidence for Popular Tradition on Hadith as Physical Object in the First Centuries of Islam. Arabica, 63(1-2), 30-63.

Mostafazadeh, A., \& Khorasani, H. R. (2014). Holy Quran and Hadith perspective on Fasting and immune system. Islam and Health Journal, 1(3), 61-68.

Muhtador, M. (2016). Sejarah Perkembangan Metode dan Pendekatan Syarah Hadis. Riwayah, 2(2), 259272.

Mustami, M. K., \& Masri, M. (2017). Produksi Anti Bakteri dari Sayap Berbagai Jenis lalat yang terilhami dari Hadis Bukhary tentang Lalat (Penelitian multiyears Terintegrasi Sains dan Agama.

Nadhiran, H. (2017). Epistemologi Kritik Hadis. Jurnal Ilmu Agama: Mengkaji Doktrin, Pemikiran, Dan Fenomena Agama, 18(2).

Nadkarni, P. M., Ohno-Machado, L., \& Chapman, W. W. (2011). Natural language processing: An introduction. Journal of the American Medical Informatics Association: JAMIA. https://doi.org/10.1136/amiajnl-2011-000464 
Nairozle, M. I., Ibrahim, M. N. A., \& Jasmi, K. A. (2018). Sains-Teknologi dan Ilmu Agama Menurut Bahasa al-Quran dan Hadis.

Najeeb, M. M. (2014). Towards innovative system for Hadith Isnad processing. Int J Comput Trends Technol, 18(6), 257-259.

Najeeb, M. M. (2015). Multi-agent system for hadith processing. International Journal of Software Engineering and Its Applications, 9(9), 153-166.

Najiyah, I., Susanti, S., Riana, D., \& Wahyudi, M. (2017). Hadith degree classification for Shahih Hadith identification web based. 2017 5th International Conference on Cyber and IT Service Management (CITSM), 1-6.

Nashiruddin, N. (2017). Interelasi Organ Tubuh Perspektif Hadis (Suatu Kajian tahlili). Universitas Islam Negeri Alauddin Makassar.

Niazi, F., Naseem, M., Khurshid, Z., Zafar, M. S., \& Almas, K. (2016). Role of Salvadora persica chewing stick (miswak): A natural toothbrush for holistic oral health. European Journal of Dentistry, 10(2), 301.

Nincarean, D., Alia, M. B., Halim, N. D. A., \& Rahman, M. H. A. (2013). Mobile Augmented Reality: The Potential for Education. Procedia - Social and Behavioral Sciences. https://doi.org/10.1016/j.sbspro.2013.10.385

Pari, F. (2017). Kontekstualitas Vs Universalitas Hadis: Problem Metodologi. Refleksi, 16(2), 187-203.

Qomarullah, M. (2016). Metode Takhrij Hadits Dalam Menakar Hadits Nabi. EL-Ghiroh, 11(2), 23-34.

Rahmasari, B. (2017). Kebersihan dan Kesehatan Lingkungan dalam Perspektif Hadis. UIN Syarif Hidayatullah Jakarta: Pascasarjana Fakultas Ushuluddin, 2017.

Rofiq, A. N. (2015). Proses reproduksi wanita dalam perspektif hadis Nabi. Epistemé: Jurnal Pengembangan Ilmu Keislaman, 10(2), 457-475.

Rohmana, J. A. (2015). Pendekatan Antropologi Dalam Studi Living Hadis Di Indonesia: Sebuah Kajian Awal. Holistic Al-Hadis, 1(2), 247-288.

Rohmatika, R. V. (2019). Pendekatan Interdisipliner dan Multidisipliner Dalam Studi Islam. Al-Adyan: Jurnal Studi Lintas Agama, 14(1), 115-132.

Safarsyah, A. I. (2018). Hadis Nabi SAW Tentang Obat Dalam Tinjauan Ilmu Kedokteran Modern. AlDzikra: Jurnal Studi Ilmu Al-Qur'an Dan Al-Hadits, 12(2), 165-188.

Sagir, A. (2017). Perkembangan Syarah Hadis dalam Tradisi Keilmuan Islam. Jurnal Ilmiah Ilmu Ushuluddin, 9(2), 129-151.

Saifullah, S. (2014). Renaissance dan Humanisme Sebagai Jembatan Lahirnya Filsafat Modern. Jurnal Ushuluddin, 22(2), 133-144.

Salmah, S. (2017). Besi Dalam Perspektif Hadis. PROCEEDING IAIN Batusangkar, 1(1), 641-658.

Saloot, M. A., Idris, N., Mahmud, R., Ja'afar, S., Thorleuchter, D., \& Gani, A. (2016). Hadith data mining and classification: a comparative analysis. Artificial Intelligence Review, 46(1), 113-128.

Setyani, D. L. (2016). Pemahaman Hadits tentang gen dalam perspektif sains. UIN Walisongo.

Shah, F. A. (2011). Pendekatan Kontekstual Dalam Memahami Hadith-Hadith Rasulullah SAW. Jurnal Islam Dan Masyarakat Kontemporari, 4, 101-120.

Shukur, Z., Fabil, N., Salim, J., \& Noah, S. A. (2011). Visualization of the hadith chain of narrators. International Visual Informatics Conference, 340-347.

Soetari, E. (1994). Ilmu Hadits. Amal Bakti Press.

Soetari, E. (2005). Ilmu Hadits: Kajian Riwayah dan Dirayah. Mimbar Pustaka.

Soetari, E. (2015). Syarah dan Kritik Hadis dengan Metode Tahrij: Teori dan Aplikasi (2nd ed.). Yayasan Amal Bakti Gombong Layang.

Solihin, S. (2016). Penelitian Hadis: Ontologi, Epistemologi dan Aksiologi. Diroyah: Jurnal Studi Ilmu Hadis, 1(1), 61-69.

Sookhdeo, P. (2006). Issues of interpreting the Koran and Hadith. Connections, 5(3), 57-82.

Sudikan, S. Y. (2015). Pendekatan interdisipliner, multidisipliner, dan transdisipliner dalam studi sastra. Paramasastra, 2(1).

Suryadilaga, M. A. (2014). Kajian Hadis Di Era Global. Jurnal Esensia, 15(2).

Suryadilaga, M. A. (2017). Pembacaan Hadis dalam Perspektif Antropologi. Al Qalam, 34(2), 265-286.

Taghavizad, R. (2011). The Healing Effect of Honey as Stated in Quran and Hadith. Quran Med, 1(2), 3-8. 
Taufik, E. T. (2020a). Epistemologi Syarah Hadis di Perguruan Tinggi: Diskursus Genealogis Terhadap Transmisi dan Transformasi Metode Syaraḥ Hadis di Indonesia. Ushuluna: Jurnal Ilmu Ushuluddin, $6(2), 33-50$.

Taufik, E. T. (2020b). Syarah Hadis Di Perguruan Tinggi: Genealogis Transmisi Dan Transformasi Metode Syarah Hadis Di Indonesia. Ushuluna: Jurnal Ilmu Ushuluddin, 6(2), 33-50.

Tim Penyusun. (2018a). Keputusan Direktur Jenderal Pendidikan Islam Nomor 6165 Tahun 2018 tentang Standar Kompetensi Lulusan dan Capaian Pembelajaran Lulusan Program Studi Jenjang Magister dan Doktor pada PTKI.

Tim Penyusun. (2018b). Keputusan Direktur Jenderal Pendidikan Islam Nomor 6994 Tahun 2018 tentang Agenda Riset Keagamaan Nasional (Arkan) 2018-2028.

Tsaqofi, M. H. A. (2018). Manfaat Katak dalam sistem kosmos: kajian Ma'ani Al Hadith dalam Sunan Abi Dawud no. Indeks 3871 dengan pendekatan sains. UIN Sunan Ampel Surabaya.

Umar, M. (2016). Konvergensi Agama dan Sains dalam Melacak Basis Ontologi Semesta: Tinjauan Hermeneutika Hadis Penciptaan. Jurnal THEOLOGIA, 27(1), 173-212.

Usman, A. H., Ismail, A. Z., Soroni, M. K., \& Wazir, R. (2015). Rise and Fall of Development: How does Hadith Views on Economic System? Asian Social Science, 11(27), 168.

Wahid, R. A. (2017). Integrasi Ilmu Dalam Hadis. PROCEEDING IAIN Batusangkar, 1(1), 565-584.

Wahid, R. A., \& Masri, D. (2018). Perkembangan Terkini Studi Hadis Di Indonesia: Peran LembagaLembaga Pendidikan dalam Pengkajian Hadis.

Wendry, N., Anshori, M., Majid, A., M Dalil, F. Y., \& Rahman, H. (2018). Paradigma Studi Hadis Kontemporer.

Williamson, K. Given, L. M., \& Scifleet, P. (2018). Qualitative data analysis. In Research Methods: Information, Systems, and Contexts: Second Edition. https://doi.org/10.1016/B978-0-08-1022207.00019-4

Yahya, M. M. H., Abidin, Z., Zaman, K., \& Basiron, B. (2018). Hubungan Sains dan Agama.

Yaqub, A. M. (2004). Autentisitas Dan Otoritas Hadis Dalam Khazanah Keilmuan Ulama Muslim Dan Sarjana Barat. Tarjih: Jurnal Tarjih Dan Pengembangan Pemikiran Islam, 7(1), 33-41.

Yusoff, Y., Ismail, R., \& Hassan, Z. (2010). Adopting hadith verification techniques in to digital evidence authentication. Journal of Computer Science, 6(6), 613.

Zohar, Y. E. (2002). Introduction to Text Mining. Automated Learning Group, University of Illinois.

Zong, Z., \& Hong, C. (2018). On application of natural language processing in machine translation. Proceedings - 2018 3rd International Conference on Mechanical, Control and Computer Engineering, ICMCCE 2018, 506-510. https://doi.org/10.1109/ICMCCE.2018.00112

Zuhri, M. (2015). Perkembangan Kajian Hadis Kesarjanaan Barat. ULUL ALBAB Jurnal Studi Islam, 16(2), $215-234$.

Zulhelmi, M. N., \& Azman, A. R. (2016). Hujan dan Banjir Dalam Hadis Nabi Saw. 